DOI: $10.17516 / 1997-1370-0534$

УДК 343.9

\title{
Revisiting the Tactics of Interrogation of an Expert in the Trial
}

\author{
Dmitry V. Kimª and Vera S. Gorshkova ${ }^{b *}$ \\ a Siberian Law Institute of the Ministry of Internal Affairs of Russia \\ Krasnoyarsk, Russian Federation \\ ${ }^{b}$ Barnaul Law Institute of the Ministry of Internal Affairs of Russia \\ Barnaul, Russian Federation
}

Received 10.10.2019, received in revised form 27.12.2019, accepted 09.01.2020

\begin{abstract}
In the modern world, forensics is actively developing; a large number of scientific studies are being carried out in this area, the results of which are subsequently introduced into the fight against crime. Effective solution and investigation of crimes is possible using modern scientific and technical means and methods, in particular the results of applying special knowledge, increasing the level of professional training of employees (investigators, interrogators, operational staff, employees of expert institutions and organizations, judges), as well as a result of implementing modern provisions of the theory of forensics in practice. One of the relatively new directions in this activity is the implementation of the concept of a situational approach in law enforcement not only during the preliminary investigation, but also in the trial of criminal cases. The use of special knowledge in criminal proceedings, namely the interrogation of an expert in court, is of increasing importance.
\end{abstract}

Keywords: investigation methodology, expert, interrogation, judicial investigation.

Research area: law.

Citation: Kim, D.V., Gorshkova, V.S. (2020). Revisiting the tactics of interrogation of an expert in the trial. J. Sib. Fed. Univ. Humanit. Soc. Sci., 13(1), 61-67. DOI: 10.17516/1997-1370-0534

\section{Introduction}

to the research problem

The possibility and necessity of using forensic knowledge in trials is currently beyond doubt; arguments in support of this thesis have been repeatedly cited by forensic scientists (Alexandrov et al., 2019: 209-210; Garmaev, Kirillova, 2015: 14; Alexandrov, 2015: 26-27). At the same time, forensic thought is actively developing forms for the implementation of this provi- sion. Thus, for example, V.K. Gavlo was of the opinion that it was necessary to study the trial from the point of view of the subject of forensic science, using the "forensic characteristics of the trial" design (Gavlo, Kim, 2010: 242-247). In turn, A.Yu. Korchagin points out the need for the use of such a concept as "forensic support of criminal trials" (Latypova, 2018).

However, both authors, like many other forensic scientists, do not question the need

(C) Siberian Federal University. All rights reserved

* Corresponding author E-mail address: kimklo@mail.ru, vera-gorshkova-86@mail.ru 
to develop tactics and methods of trial within the proposed entities (Gavlo, 1985: 289; Kim, 2009; Komissarov, 2009: 18-20).

Pre-trials and trials are a single and indivisible field of activity for the science of forensics. It is impossible to develop forensic techniques, tactics and methods for preliminary investigation without taking into account the situations of the trial (first of all, its central part that is judicial investigation), as well as forensic techniques, tactics and methods of the trial without taking into account the situations of the preliminary investigation and the activities of participants in criminal proceedings.

Moreover, forensic tactics is of special scientific value in the context of scientific research in the field of forensics; it is its "thinking device", which is primary in relation to the forensic technique from the point of view of the moment of occurrence and the source of the tools used (Sergeev, Sergeev, 2018: 250-251).

One of the main tactical and forensic tools used to break the data of the science of forensic science in the context of a trial is the forensic (investigative) situation. Back in the early 2000 s, forensic science outlined a steady trend in the development of a situational approach in relation to trials. Analysis of modern scientific literature allows us to state its preservation and development at the present time (Knyazkov, 2012: 26-31; Titova, 2015: 3-7; Vasiliev, 1976: 73-75; Vinberg, 1965: 117-119).

Defining the judicial situation as a complex dynamic system possessing an informational nature that develops while the court (judge) carries out their activities, influencing the court decision and the future in the criminal case (Kislenko, 2019: 291), we consider it necessary to pay close attention to judicial situations that arise during the interrogation of an expert, their resolution and correlation with the concept of "expert situation".

\section{Statement of the problem}

In 1997, R.S. Belkin in "Forensic Encyclopaedia" indicated that the expert situation is "a system of factors that serve as the basis for putting forward the most likely expert versions, the choice of methods for checking them, and planning the investigation" (Belkin, 1987:
265-266). E.B. Stativa understands a forensic situation as "a combination of circumstances requiring verification or proof using special construction and technical knowledge in a civil case in an arbitration process" (Vasiliev, 1971: 16). The essence and content of the expert situation in scientific literature is revealed in relation to the solution of expert problems in the course of conducting forensic examinations or studies, which naturally means using the term "judicial situation arising during the interrogation of an expert and "expert situation" for various phenomena that arise during a trial. In the first case, we deal with situations that arise during the production of "interrogation of an expert" judicial action, and that arise during the production of "appointment and production of a judicial examination" investigative and judicial action in the second case.

Interrogation of an expert in court is a very common form of participation of employees of forensic departments, organizations and individuals who have conducted forensic examination in criminal, civil, arbitration, and administrative cases. However, this procedural action is problematic for all participants in the trial, the court, and to a greater extent for the expert. The tactics of interrogation, including interrogation of the expert at the stage of the preliminary investigation, are quite fully developed by the science of forensics, while the tactics of interrogation of the expert in the trial are practically ignored. In the scientific literature, one can find isolated studies on this subject. Thus, for example, I.A. Shalkevich formulated general rules, on the basis of which the tactics of interrogating an expert should be built (Volchetskaya, 1997: 95-97). At the same time, he points out that the main range of questions that may be used to interrogate an expert in court must necessarily relate to objects examined by an expert during a forensic examination, the results of which are reflected in the conclusions. It is not allowed to pose questions that require additional research using special knowledge as this requires additional or repeated examination (Volchetskaya, 1997: 95-97).

We fully support A.S. Knyazkov, who claims that "in relation to methodological and forensic works, one can speak of a certain es- 
tablished style of research, when "the final product" that is a private forensic investigation methodology takes on the form of "a set of rules" for the investigator, where the emphasis is made not on the investigative situation's conditionality of the investigation actions' tactical methods, but only on its conditionality of investigative actions" (Knyazkov, 2016: 4).

\section{Discussion}

The analysis of forensic investigative practice allows us to distinguish the following typical forensic situations that develop during the interrogation of an expert in a court session:

1) interrogation of an expert in a conflict-free situation (it is necessary to explain to the court special terms, formulations, formulas, used techniques, equipment and tools during the production of forensic examination, etc.);

2) interrogation of an expert in a conflict situation (if the conclusions in the assistant's or the expert's opinion submitted by the defence or the prosecution differ).

When conducting an interrogation in court, one should adhere to the general algorithm, observing which it is possible to obtain a complete, clear idea of the main points of the expert's conclusion:

- information about the expert institution in which the expert report was made (state or non-state expert institution, material and technical base, tools, equipment, their licensing, availability of quality certificates, calibration certificates for measuring instruments, compliance with the requirements for working with certain substances, objects, etc., the presence or absence of control by the head of the quality and completeness of the expert study);

- general characteristics of the expert who conducted the examination (education, work experience in a specific expert field, the number of examinations performed in this field in recent 1-3 years, internships, advanced training, for non-state experts it includes the presence or absence of a certificate / license);

- description of the objects presented to the expert for production (including how they arrived at the expert institution - on purpose or by mail, the presence or absence of packaging, sufficiency for the study, namely, if the expert was provided with additional samples and other materials, without which it is impossible or difficult to solve tasks posed to the expert);

- applied research methods and methodology (the availability of certification, its approbation and implementation of expert units in the activities, recommendations for use, including the possibility of providing a paper copy at the hearing), as well as the use of additional research methods and their capabilities (for example, during the production of handwriting examinations, where the study object is a signature, they use the method of studying the pressure characteristics of the performer's signature according to the nature of the distribution of rafts awns dye strokes).

- findings based on the results of an expert study (categorical, probable or it was not possible to resolve the issue on the merits), their validity, reliability and correlation with other evidence.

When interrogating an expert in a conflict-free situation, it is necessary for the interrogated person at the hearing to have training, methodological, reference books and other sources recommended for conducting forensic examinations, which allow for objective and full presentation of explanations and additions to the court based on the expert's opinion.

When interrogating an expert in a conflict situation, it becomes necessary to clarify at the hearing the reasons for the occurrence of contradictions, ways to explain and eliminate them. In this case, it is necessary at the hearing to pose the following questions before the expert or assistant:

- which coinciding (and) or differing features of the objects exactly were the basis for the conclusions of the expert (assistant), if they form a set that is reliable and sufficient to form the final result; besides, it is necessary to demonstrate them to the participants in the court session in the form of an illustration table to the expert's opinion or visual display;

- how the expert experiment was carried out, what objects, materials and equipment were used;

- whether additional samples or objects were required to perform a forensic examination (research); 
- why the conclusion is given in a probable form; under what circumstances it is possible to resolve the questions posed to the expert in a categorical form.

Often when there is a discrepancy in the conclusions of experts or an expert and an assistant, repeated examinations and additional examinations in more rare cases are carried out. At the hearing, it is also possible to eliminate the contradictions in previous expert studies (expert opinions). For example, an expert who conducted one of the handwriting examinations was provided with a large number of handwriting samples and signatures. That comparative material was necessary and sufficient for conducting an expert study and made it possible to resolve the issue of the performer in a categorical form.

After announcing the expert's opinion or assistant's opinion made by them, each expert must be given the opportunity to comment on the study, namely if they agree or disagree with their findings, the conclusions of another expert (assistant), as well as comment in detail on the conclusions of the other party - significant violations of the examination procedure, expert methodology choice and other provisions that may affect the validity and reliability of the expert's (assistant's) conclusion.

In case of doubt about the validity and reliability of the conclusions of the experts, the expert and the assistant, it is necessary to conduct a second forensic examination with the obligatory submission of the protocol (s) of the interrogation of the expert or the assistant in court to a new expert.

\section{Conclusion}

The identification and study of these and other situations that arise in the process of trial of criminal cases will contribute to the development of tactics of conducting procedural actions, which is the prerogative of forensic science, while the application of the situational approach in the process of trial, in general, is a correct and promising direction that meets today's realities and forensic science trends.

\section{References}

Alexandrov, I.V. (2015). Ob aktual'nykh napravleniiakh razvitiia kriminalistiki [Concerning the topical aspects of the development of criminalistics]. In Sovremennaia kriminalistika: problemy. tendentsii. perspektivy. Materialy Mezhdunarodnoi nauchno-prakticheskoi konferentsii, posviashchennoi 90-letiiu so dnia rozhdeniia Zasluzhennogo deiatelia nauki RF, Zasluzhennogo iurista RSFSR, doktora iuridicheskikh nauk, professora Nikolaia Pavlovicha Iablokova. Moskva, 22 dekabria 2015 g. [Modern forensics: problems, trends, prospects. Proceedings of the International Research-to-Practice Conference dedicated to the $90^{\text {th }}$ anniversary of the Honoured Scientist of the Russian Federation, Honoured Lawyer of the RSFSR, Doctor of Law, Professor Nikolay Pavlovich Yablokov. Moscow, December 22, 2015]. Moscow, 26-27.

Alexandrov, A.I., Alexandrov, R.A., Antonov, I.A., Vekhov, V.B., Danilova, N.A., Elagina, E.V., Kirillova, N.P., Kornienko, N.A., Kushnirenko, S.P., Merkulova, Yu.S., Miklyaeva, O.V., Nazarov, A.D., Nizamov, V.Yu., Novikov, S.A., Petrov, V.V., Pristiskov, V.D., Sedova, T.A., Sidorova, N.A., Stoiko, N.G., Kharatishvili, A.G., Kholopov, A.V. (2019). Kriminalistika [Forensics]. Moscow, Izd-vo KnoRus, 712 p.

Belkin, R.S. (1977). Kurs sovetskoi kriminalistiki. T. 1. Obshchaia teoriia sovetskoi kriminalistiki [The course of Soviet forensics. Vol. 1. General theory of Soviet forensics]. Moscow, Izd-vo RIO Akademii MVD SSSR, 338 p.

Belkin, R.S. (1987). Kriminalistika: problemy, tendentsii, perspektivy. Obshchaia i chastnaia teorii [Forensics: problems, trends, prospects. General and particular theory]. Moscow, Izd-vo Iuridicheskaia literatura, $271 \mathrm{p}$.

Belkin, R.S. (1997). Kriminalisticheskaia entsiklopediia [Forensic Encyclopedia]. Moscow, 334 p.

Flyagin, Yu.A. (2016). Kriminalisticheskie situatsii sudebnogo razbiratel'stva po ugolovnym delam o nezakonnom oborote sil'nodeistvuiushchikh i iadovitykh veshchestv v tseliakh sbyta [Forensic situations in criminal proceedings on the illicit trafficking of potent and toxic substances for marketing]. In Ugolov- 
no-protsessual'nye i kriminalisticheskie chteniia na Altae [Criminal procedure and forensic readings in Altai], 117-119.

Garmaev, Yu.P., Kirillova, A.A. (2015). Kriminalisticheskaia metodika sudebnogo razbiratel'stva po ugolovnym delam ob ubiistvakh (ch. I st. $105 \mathrm{UK} R F$ ): teoreticheskie osnovy i prikladnye rekomendatsii: Monografiia i prakticheskoe posobie [Criminalistic Methodology of the Trial on Criminal Cases of Murders (part 1 of Article 105 of the Criminal Code of the Russian Federation): theoretical foundations and applied recommendations: Monograph and practical guide]. Moscow, Izd-vo Iurlitinform, $280 \mathrm{p}$.

Gavlo, V.K. (2011). Izbrannye trudy [Selected Works]. Barnaul, Izdatel'stvo Altaiskogo universiteta, $850 \mathrm{p}$.

Gavlo, V.K. (2010). Kriminalisticheskoe obespechenie predvaritel'nogo i sudebnogo sledstviia kak zadacha kriminalisticheskoi metodiki [Forensic support of preliminary and judicial investigation as a task of forensic techniques]. In Kriminalistika XXI stoletiia: materialy mezhdunar. nauch. - prakt. konf., 25-26 listop. 2010 g. X. [Forensic science of the 21 ${ }^{\text {st }}$ century: Proceedings of the International Research-to-Practice Conference, 25-26 November, 2010]. Moscow, Pravo, 242-247.

Gavlo, V.K., Kim, D.V. (2010). Taktika i metodika sudebnogo sledstviia - est sfera prilozheniia nauchnogo potentsiala kriminalistiki [Tactics and methods of judicial investigation is the scope of the scientific potential of criminalistics]. In Aktual'nye voprosy kriminalisticheskogo obespecheniia ugolovnogo sudoproizvodstva: Mat-ly vseros. nauchno-prakt. konferentsii [Major Aspects of Forensic Support of Criminal Trial: Proceedings of All-Russian Research-to- Practice Conference]. Irkutsk, Izd-vo BGUEP, 289.

Gavlo, V.K. (1985). Teoreticheskie problemy i praktika primeneniia metodiki rassledovanii otdelnykh vidov prestuplenii [Theoretical problems and the practice of applying investigation methods for certain types of crimes]. Tomsk, Izdatel'stvo Tomskogo universiteta, $333 \mathrm{p}$.

Kim, D.V. (2009). Problemy teorii i praktiki razresheniia kriminalisticheskikh situatsii v protsesse raskrytiia, predvaritel'nogo rassledovaniia i sudebnogo rassmotreniia ugolovnykh del: / diss. ... d-ra iurid. nauk: 12.00.09 / Dmitrii Vladimirovich Kim [Problems of the theory and practice of resolving forensic situations in the process of solving, preliminary investigation and trial of criminal cases: Doctoral Thesis (12.00.09)]. Barnaul, 428 p.

Kislenko, S.L. (2019). Tipovoi algoritm deistviia prokurora v problemnykh situatsiiakh podderzhaniia gosudarstvennogo obvineniia [A typical algorithm for the actions of the prosecutor in problematic situations of supporting government]. In Iuridicheskoye obrazovanie i nauka [Legal education and science], 5, 26-31.

Knyazkov, A.S. (2012). Kontseptual'nye polozheniia takticheskogo priema [Conceptual provisions of tactical technique]. Tomsk, Izd-vo Tomskogo universiteta, $190 \mathrm{p}$.

Knyazkov, A.S. (2016). Problemy predmeta kriminalisticheskoi taktiki [Problems of the subject of forensic tactics]. In Aktual'nye problemy bor'by s prestupleniiami i inymi pravonarusheniiami [Major Aspects of the Fight against Crimes and Other Offenses], 14(1), 18-20.

Komissarov, V.I. (2009). Kriminalisticheskaia taktika: istoriia, sovremennoe sostoianie i perspektivy razvitiia [Forensic tactics: history, current status and development prospects]. Moscow, Izdatel'stvo Iurlitinform, $192 \mathrm{p}$.

Korchagin, A.Yu. (2008). Organizatsionno-takticheskie i metodicheskie osnovy kriminalisticheskogo obespecheniia sudebnogo razbiratel'stva ugolovnykh del: diss. ... d-ra iurid. nauk: 12.00.09 [Organizational-tactical and methodological foundations of forensic support for the trial of criminal cases: Doctoral Thesis (12.00.09)]. Krasnodar, 355 p.

Latypova, K.S. (2018). K voprosu o tipichnykh sudebnykh situatsiiakh po ugolovnym delam o dorozhno-transportnykh prestupleniiakh, sviazannykh s naezdami na peshekhodov i rekomendatsii gosudarstvennomu obviniteliu po ikh razresheniiu [Revisiting typical trial situations in criminal cases of road traffic crimes related to pedestrian accidents, and recommendations to the public prosecutor on their resolution]. In Aktual'nye problemy sovremennoi iuridicheskoi nauki i praktiki: materialy Mezhdunarodnoi nauchno-prakticheskoi konferentsii: $k$ iubileiu doktora iuridicheskikh nauk, professora, zasluzhennogo iurista Rossiiskoi Federatsii Iuriia Il'icha Skuratova [Topical Issues of Modern Legal Science and Practice: Proceedings of the International Research-to-Practice Conference: Dedicated to the Jubilee of 
Doctor of Law, Professor, Honoured Lawyer of the Russian Federation Yuri Ilyich Skuratov]. Ulan-Ude, 224-232.

Sergeev, A.B., Sergeev, K.A. (2018). Otdel'nye sudebnye situatsii pri priniatii reshenii o naznachenii prinuditel'nykh mer meditsinskogo kharaktera [Certain trial situations when making decisions on the sentence of compulsory medical treatment], In Meditsinskoe pravo [Medical Law], 1, 3-7.

Shalkevich, I.A. (2017). Taktika doprosa sudebnogo eksperta [Tactics of interrogation of a judicial expert]. In Traditsii i perspektivy razvitiia kriminalisticheskoi taktiki: Materialy kruglogo stola s mezhdunarodnym uchastiem. Belorusskii gosudarstvennyi universitet (Minsk) [Traditions and prospects for the development of forensic tactics: Round table proceedings with international participation. Belarussian State University (Minsk)]. Minsk, 95-97.

Stativa, E.B. (2016). Tipologiia sudebno-ekspertnykh situatsii $v$ arbitrazhnom protsesse, trebuiushchikh dlia svoego razresheniia ispol'zovaniia spetsialnykh stroitel;no-tekhnicheskikh znanii [Typology of forensic expert situations in the arbitration process requiring the use of special construction and technical knowledge to solve them]. In Teoriia i praktika sudebnoi ekspertizy [Theory and Practice of Forensics], 1 (41), 16.

Titova, K.A. (2015). Sudebno-kriminalisticheskie situatsii i ikh razreshenie v protsesse sudebnogo razbiratel'stva po delam o khishcheniiakh, sovershaemykh dolzhnostnymi litsami v sfere zhilishchno-kommunal'nogo khoziaistva [Forensic situations and their resolution in the trial of embezzlement cases committed by officials of housing and communal services]. In Vestnik Krasnodarskogo universiteta MVD Rossii [Bulletin of Krasnodar University of the Ministry of Internal Affairs of Russia], 2 (28), 73-75.

Vasiliev, A.N. (1971). Kriminalistika [Forensics]. Moscow, Izd-vo Moskovskogo universiteta, 564 p.

Vasiliev, A.N. (1976). Sledstvennaia taktika [Iinvestigative tactics]. Moscow, 197 p.

Vinberg, A.I. (1965). O nauchnykh osnovakh kriminalisticheskoi taktiki [Concerning the scientific foundations of forensic tactics]. In Pravovedenie [Jurisprudence], 3, 78-83.

Volchetskaya, T.S. (1997). Kriminalisticheskaia situalogiia: diss. ... d-ra iurid. nauk: 12.00 .09 [Forensic Situation. Doctoral Thesis (12.00.09)]. Moscow, 395 p. 


\title{
К вопросу о тактике допроса эксперта \\ в судебном разбирательстве
}

\author{
Д.В. Кима , В.С. Горшкова \\ ${ }^{a}$ Сибирский юридический институт МВД России \\ Российская Федерачия, Красноярск \\ ${ }^{\sigma}$ Барнаульский юридический институт МВД России \\ Российская Федерация, Барнаул
}

\begin{abstract}
Аннотация. В современном мире криминалистика активно развивается, в данной области производится большое количество научных исследований, результаты которых в дальнейшем внедряются в борьбу с преступностью. Эффективное раскрытие и расследование преступлений возможно при использовании современных научно-технических средств и методов, в частности результатов применения специальных познаний, повышении уровня профессиональной подготовки сотрудников (следователей, дознавателей, оперативных сотрудников, сотрудников экспертных учреждений и организаций, судей), а также при внедрении современных положений теории судебной экспертизы и криминалистики в практику. Одним из относительно новых направлений в этой деятельности является реализация концепции ситуационного подхода в правоприменительной деятельности - в ходе не только предварительного расследования, но и судебного разбирательства уголовных дел. Все большее значение при этом занимает использование специальных познаний в уголовном судопроизводстве, а именно допрос эксперта в суде.
\end{abstract}

Ключевые слова: методика расследования, эксперт, допрос, судебное следствие.

Научная специальность: 12.00.00 - юридические науки. 